\title{
Mengurai Relasi Konsumsi Rumah Tangga, Belanja Pemerintah dan Investasi Terhadap Akselerasi Pertumbuhan Ekonomi
}

\author{
Nurfadilah Sarimunding ${ }^{1}$ \\ Sitti Aisyah ${ }^{2}$ \\ 1,2, Program Studi IImu Ekonomi \\ Fakultas Ekonomi dan Bisnis Islam Universitas Islam Negeri Alauddin Makassar \\ Jl. Yasin Limpo, No. 36 Samata, Gowa Sulawesi Selatan \\ E-mail :dnurfa9@gmail.com¹ ${ }^{1}$, sitti.aisyah.s@uin-alauddin.ac.id ${ }^{2}$
}

\section{Abstrak: Mengurai Relasi Konsumsi Rumah Tangga, Belanja Pemerintah dan Investasi Terhadap Akselerasi Pertumbuhan Ekonomi}

Pertumbuhan ekonomi di Kabupaten Polewali Mandar, bergerak tidak begitu akseleratif sementara pengeluaran konsumsi, pengeluaran pemerintah dan investasi pemerintah, dari tahun ke tahun semakin besar. Kontradiksi faktual tersebut, melatarbelakangi peneliti ini untuk menelusur masalah tersebut. Dalam penelitian ini bertujuan untuk mengetahui pengaruh konsumsi rumah tangga, belanja pemerintah dan investasi terhadap pertumbuhan ekonomi di Kabupaten Polewali Mandar. Penelitian ini menggunakan jenis penelitian kuantitatif dan data diolah dengan kebutuhan model yang digunakan . Teknik pengolahan data menggunakan regresi linear berganda melalui program SPSS. Adapun data yang digunakan dalam penelitian ini merupakan data sekunder, dengan jenis data time series tahunan periode 2008-2017 yang di peroleh dari BPS (Badan Pusat Statistik). Variabel yang dugunakan adalah pertumbuhan ekonomi, konsumsi rumah tangga, belanja pemerintah dan investasi. Hasil penelitian ini menunjukkan bahwa pengeluaran konsumsi rumah tangga berpengaruh secara signifikan dan berhubungan positif terhadap pertumbuhan ekonomi, belanja pemerintah tidak berpengaruh signifikan tetapi berhubungan positif terhadap pertumbuhan ekonomi, investasi tidak berpengaruh secara signifikan tetapi berhungan positif terhadap pertumbuhan ekonomi di Kabupaten Polewali Mandar tahun 2008-2017. Sedangkan secara bersama-sama variabel konsumsi rumah tangga, belanja pemerintah dan investasi berpengaruh terhadap pertumbuhan ekonomi di Kabupaten Polewali Mandar.

Kata Kunci: Pertumbuhan, Konsumsi, Belanja Pemerintah. 


\section{Abstract: Deciphering Household Consumption Relationships, Government Expenditures and Investment to Acceleration of Economic Growth}

Economic growth in Polewali Mandar Regency, is moving less acceleratively while consumption expenditures, government spending and government investment, are increasing from year to year. The factual contradiction behind this researcher is to trace the problem. In this study aims to determine the effect of household consumption, government spending and investment on economic growth in Polewali Mandar District. This study uses a type of quantitative research and data is processed with the needs of the model used. Data processing techniques use multiple linear regression through the SPSS program. The data used in this study is secondary data, with annual time series data types for the period 20082017 obtained from BPS (Central Bureau of Statistics). The variables used are economic growth, household consumption, government spending and investment. The results of this study indicate that household consumption expenditure has a significant effect and is positively related to economic growth, government spending has no significant effect but is positively related to economic growth, investment has no significant effect but has a positive effect on economic growth in Polewali Mandar District in 2008-2017. While the variables of household consumption, government spending and investment have an effect on economic growth in Polewali Mandar Regency.

Keywords: Growth, Consumption, Government Expenditures.

\section{PENDAHULUAN / INTRODUCTION}

Pertumbuhan ekonomi di Kabupaten Polewali Mandar, bergerak tidak begitu akseleratif dan tidak inklusif. Disaat yang sama pengeluaran konsumsi, belanja pemerintah dan investasi, dari tahun ke tahun semakin besar. Kontradiksi faktual tersebut, mengafirmasi bahwa terjadi pertumbuhan semu. Masalah mendasar dalam proses pertumbuhan ekonomi bukan hanya bagaimana menumbuhkan perekonomian secara cepat, namun juga terkait dampak dari pertumbuhan tersebut, mesti benar-benar dapat dirasakan secara nyata oleh masyarakat. Bisa saja sebagian besar hasil pertumbuhan ekonomi tersebut, hanya dinikmati oleh sebagian kecil masyarakat yang sudah kaya sehingga yang kaya makin kaya, sedangkan yang miskin tidak mengalami perbaikan penghidupan. Anjuran-anjuran keynesian menjadi kiblat pembangunan oleh pemerintah, yang diyakini bahwa pertumbuhan pendapatan ditentukan oleh besarnya pengeluaran konsumsi, pengeluaran pemerintah dan investasi. Dengan demikan, untuk meningkatkan pertumbuhan ekonomi yang diukur pada peningkatan pendapatan, maka diperlukan peningkatan konsumsi, pengeluaran pemerintah dan investasi. 


\section{TINJAUAN TEORITIK / LITERATURE REVIEW}

\section{Pertumbuhan Ekonomi}

Menurut pandangan ekonom klasik, Adam Smith (1759) mengemukakan bahwa pada dasarnya ada empat faktor yang mempengaruhi pertumbuhan ekonomi yaitu: (1). jumlah penduduk. (2). jumlah stok barang modal. (3). luas tanah dan kekayaan alam. (4). tingkat teknologi yang digunakan. Pertumbuhan ekonomi yang tinggi dan prosesnya yang berkelanjutan merupakan kondisi utama bagi kelangsungan pembangunan ekonomiPertumbuhan ekonomi menunjukkan sejauh mana aktivitas perekonomian akan menghasilkan tambahan pendapatan masyarakat pada suatu periode tertentu. Dengan kata lain, perekonomian dikatakan mengalami pertumbuhan bila pendapatan rill masyarakat pada tahun tertentu lebih besar dari pada pendapatan rill masyarakat pada tahun sebelumnya.

Berbeda dengan Salvatore (2006) yang mengemukakan gagasan-gagasan yang cukup Keynesian, yang mengatakan bahwa dalam kegiatan perekonomian yang sebenarnya pertumbuhan ekonomi dimaknai sebagai perkembangan fiskal produk barang dan jasa yang berlaku disuatu negara, seperti pertambahan produksi barang industri, perkembangan infrastruktur, pertambahan jumlah sekolah, pertambahan produksi sektor jasa dan pertambahan produksi barang modal. Tetapi, dengan menggunakan berbagai jenis data produksi adalah sangat sukar untuk memberikan gambaran tentang pertumbuhan ekonomi yang dicapai. Oleh sebab itu, untuk memberikan suatu gambaran kasar mengenai pertumbuhan ekonomi yang dicapai suatu negara, ukuran yang selalu digunakan adalah tingkat pertumbuhan pendapatan nasional rill yang dicapai. Pertumbuhan ekonomi pada dasarnya diartikan sebagai suatu proses dimana PDB rill atau pendapatan rill per kapita meningkat secara terus menerus melalui kenaikan produktivitas perkapita. Teori klasik yang beranggapan tanpa campur tangan pemerintah dalam ekonomi, maka pembangunan ekonomi berjalan maksimal. Tetapi ternyata pada tahun 1930-an terjadi pengangguran besar-besaran. Sehingga timbullah kritik dari Keynes dengan pendekatan dari segi makro untuk mengatasi terjadinya pengangguran yaitu melihat perekonomian secara keseluruhan. Jadi untuk mengatasi pengangguran, Keynes perlu menambha pengeluaran uang supaya pengusaha menaikkan investasi yang akan menaikkan tenaga kerja. Sehingga perlu campur 
tangan pemerintah dengan mencetak uang maka akhirnya daya beli masyarakat bertambah dan respon pengusaha menaikkan produksi.

Amartya Sen (1999) pertumbuhan ekonomi yang dinyatakan dengan peningkatan output dan pendapatan rill perkapita, memang bukanlah satu-satunya sasaran kebijaksanaan di negara-negara berkembang, namun kebijaksanaan ekonomi menaikkan tingkat pertumbuhan output, perlu dilakukan dengan meningkatkankan aksesibilitas dan kapabilitas masyarakat secara umum. Peningkatan aksesibilitas tersebut akan menciptakan pertumbuhan ekonomi yang lebih inklusif, hal itu dipandang penting karena: (1). pertumbuhan ekonomi dipandang sebagai suatu syarat yang sangat diperlukan untuk perbaikan kesejahteraan masyarakat. (2). pertumbuhan ekonomi dipandang sebagai suatu prasyarat untuk mencapai tujuan-tujuan pembangunan lainnya, seperti: peningkatan pendapatan dan kekayaan masyarakat, ataupun penyediaan fasilitas dan sarana sosial lainnya.

\section{Konsumsi Rumah Tangga}

Dumairy, (1999) mengemukakan bahwa nilai perbelanjaan yang dilakukan oleh rumah tangga untuk membeli barang dan jenis kebutuhannya dalam satu tahun tertentu, dinamakan pengeluaran konsumsi rumah tangga atau dalam analisis makro ekonomi lebih lazim disebut sebagai konsumsi rumah tangga. Pendapatan yang diterima oleh rumah tangga akan digunakan untuk membeli makanan, membeli pakaian, membiayai jasa pengangkutan, membayar pendidikan anak, membayar sewa rumah dan membeli

kendaraan. Barang-barang tersebut dibeli rumah tangga untuk memenuhi kebutuhannya dan perbelanjaan disebut dinamakan konsumsi, yaitu membeli barang dan jasa untuk memuaskan keinginan memiliki dan menggunankan barang tersebut.

Pola konsumsi masyarakat berdasarkan alokasi penggunaannya dapat digolongkan kedalam kelompok-kelompok penggunaan, yaitu pengeluaran untuk makanan dan bukan makanan. Pola konsumsi masyarakat Indonesia dalam kurun waktu dua puluh tahun, hampir tidak mengalami perubahan. Pada tahun 1984 konsumsi masyarakat Indonesia sekitar $63,24 \%$ dari konsumsinya dialokasikan untuk makanan dan setiap tahun terus mengalami penurunan sehingga mencapai 6,86\% pada tahun 1993. Faktor -faktor pengeluaran konsumsi adalah pendapatan, selera, faktor sosial kultur, kekayaan, hutang pemerintah, capital gain, tingkat suku bunga, tingkat harga, money illusion, distribusi, umur, letak geografis, dan distribusi pendapatan. Pada dasarnya faktor yang paling berpengaruh 
terhadap konsumsi adalah pendapatan, namun tidak dapat dipengaruhi terhadap faktorfaktor yang lain, yang cukup berpengaruh kuat terhadap konsumsi masyarakat. Salah satu kebijakan fiskal oleh pemerintah.

Kebijakan fiskal dimaknai sebagai kebijakan penyesuaian dibidang pengeluaran dan penerimaan pemerintah untuk memperbaiki keadaan ekonomi, atau dapat juga dikaitkankebijakan fiskal adalah suatu kebijakan ekonomi dalam rangka mengarahkan kondisi perekonomian untuk menjadi lebih baik dengan jalan mengubah penerimaan dan pengeluaran pemerintah. Tidak semua transaksi yang dilakukan oleh rumah tangga digolongkan sebagai konsumsi (rumah tangga). Kegiatan rumah tangga untuk mrmbeli rumah digolongkan sebagai investasi. Seterusnya, sebagian pengeluaran mereka, seperti membayar asuransi dan mengirim uang kepada orang tua (atau anak yang sedang bersekolah) tidak digolongkan sebagai konsumsi karena ia tidak merupakan perbelanjaan terhadap barang dan jasa yang dihasilkan dalam perekonomian.

Dalam teori Keynes menduga bahwa, kecenderungan mengkonsumsi marginal (Marginal Proponsity to Consume) jumlah yang dikonsumsi dalam setiap tambah pendapatan adalah anatara nol dan satu. Kecenderungan mengkonsumsi marginal adalah krusial bagi rekomendasi kebijakan Keynes untuk menurunkan pengangguran yang kian meluas. Kekuatan kebijakan fiskal, untuk mempengaruhi perekonomian seperti ditunjukan oleh pengganda kebijakan fiskal muncul dari umpan balik antara pendapatan dan konsumsi.

Kedua, Keynes menyatakan bahwa rasio konsumsi terhadap pendapatan yang disebut kecenderungan mengkonsumsi rata-rata (Average Propensity to Consume), turun ketika pendapatan naik. Ia percaya bahwa tabungan adalah kemewahan, sehingga ia berharap orang kaya menabung dalam proporsi yang lebih tinggi dari pendapatan mereka ketimbang orang miskin. Ketiga, Keynes berpendapat bahwa pendapatan merupakan determinan konsumsi yang penting dan tingkat bunga tidak memiliki peranan penting. Keynes mengatakan bahwa pengaruh tingkat bunga terhadap konsumsi, hanya sebatas teori. Kesimpulannya bahwa pengaruh jangka pendek dari tingkat bunga terhadap pengeluaran individu dari pendapatannya bersifat sekunder dan relatif tidak penting. 


\section{Belanja Pemerintah}

Keynes dalam Mankiw (2007) dan Dumairy (1996) berpendapat bahwa pendapatan total perekonomian dalam jangka pendek sangat ditentukan oleh keinginan rumah tangga, perusahaan dan pemerintah untuk membelanjakan pendapatannya. Kenaikan pengeluaran yang direncanakn akan menyebabkan peningkatan permintaan agregat. Permintaan agregat akan mendorong produksi barang dan jasa, yang akan menyebabkan pendapatan juga akan meningkat. Pengeluaran pemerintah adalah bagian dari kebijakan fiskal, yaitu suatu tindakan pemerintah untuk mengatur jalannya perekonomian dengan cara menentukan besarnya penerimaan dan pengeluaran pemerintah setiap tahunnya, yang tercermin dalam dokumen Anggaran Pendapatan Belanja Negara (APBN) untuk nasional dan Anggaran Pendapatan Belanja Daerah (APBD) untuk daerah atau regional. Tujuan dari kebijakan fiskal ini adalah dalam rangka menstabilkan harga, tingkat output, maupun kesempatan kerja dan memacu atau mendorong pertumbuhan ekonomi.

Peranan atau campur tangan pemerintah masih sangat diperlukan yaitu apabila perekonomian sepenuhnya diatur oleh kegiatan dipasar bebas, bukan saja perekonomian tidak selalu mencapai tingkat kesempatan kerja penuh tetapi juga kestabilan kegiatan ekonomi tidak dapat diwujudkan. Akan tetapi, fluktuasi kegiatan ekonomi yang lebar dari satu periode ke periode lainnya dan ini akan menimbulkan implikasi yang serius kepada kesempatan kerja dan pengangguran dan tingkat harga. Menurut UU No. 23 Tahun 2014 tentang Pemerintah Daerah, belanja daerah adalah semua kewajiban daerah yang diakui sebagai pengurang nilai kekayaan bersih dalam periode anggaran yang bersangkutan. Belanja daerah sebagaimana dimaksud dalam Peraturan Menteri Dalam Negeri Nomor 52 Tahun 2015 tentang Pedoman Pengelolaan Keuangan Daerah, menyebutkan bahwa belanja daerah dipergunakan dalam rangka mendanai pelaksanaan urusan pemerintah yang menjadi kewenangan provinsi atau kabupaten/kota yang terdiri dari urusan wajib, urusan pilihan dan urusan yang penangannya dalam bagian atau bidang tertentu yang dapat dilaksanakan bersama antara pemerintah dan pemerintah daerah atau antar pemerintah daerah yang ditetapkan berdasarkan peraturan perundang-undangan. Pengeluaran pemerintah versi Keynes, merupakan salah satu unsur permintaan agregat. Konsep perhitungan pendapatan nasional dengan pendekatan pengeluaran bahwa $Y=C+I+G+X-M$, formula ini dikenal sebagai identitas pendapatan nasional. Variabel $Y$ melambangkan pendapatan nasional sekaligus mencerminkan penawaran agregat. Variabel-variabel di ruas kanan disebut permintaan agregat. Variabel G melambangkan belanja pemerintah, dengan 
membandingkan nilai G terhadap Y serta mengamati dari waktu ke waktu dapat diketahui seberapa besar konstribusi belanja pemerintah dalam pembentukan pendapatan nasional.

Namun pandangan tersebut, berbeda dengan teori pembangunan dan pengeluaran pemerintah yang dikembangkan oleh Rostow dan Musgrave dalam Mangkoesoebroto, (2008) yang menghubungkan pengeluaran pemerintah dengan tahap-tahap pembangunan ekonomi yang dibedakan antara tahap awal, tahap menengah dan tahap lanjut: (1) tahap awal, pada tahap awal perkembangan ekonomi persentase investasi besar, sebab pemerintah harus menyediakan prasarana, seperti pendidikan, kesehatan, prasarana transportasi dan sebagainya. (2) tahap menengah, investasi pemerintah tetap diperlukan untuk meningkatkan pertumbuhan ekonomi agar dapat tinggal landas, namun peranan investasi swasta sudah semakin membesar. (3) tahap lanjut, pembangunan ekonomi dan aktivitas pemerintah beralih dari pennyediaan prasarana ke pengeluaran-pengeluaran untuk aktivitas sosial seperti program kesejahteraan hari tua dan program pelayanan dan kesehatan masyarakat.

\section{Belanja langsung}

Belanja langsung adalah bagian belanja yang dianggarkan terkait secara langsung dengan pelaksanaan program dan kegiatan. Seperti belanja pegawai, belanja barang dan jasa, serta belanja modal untuk melaksanakan program dan kegiatan pemerintah daerah dan telah dianggarkan oleh pemerintah daerah.

a. Belanja pegawai adalah pengeluaran untuk upah, lembur dan pengeluaran lain untuk meningkatkan motivasi dan kualitas pegawai dalam melaksanakan program dan kegiatan pemerintah daerah.

b. Belanja barang dan jasa adalah pengeluaran yang digunakan untuk pembelian/pengadaan barang yang nilai manfaatnya kurang dari setahun dan atau pemakaian jasa dalam melaksanakan program dan kegiatan pemerintah daerah.

c. Belanja modal adalah pengeluaran yang digunakan untuk pembelian atau pembangunan aset tetap berwujud yang nilai manfaatnya lebih dari setahun dan atau pemakaian jasa dalam melaksanakan program dan kegiatan pemerintah suatu daerah.

2. Belanja tidak langsung

belanja tidak langsung adalah bagian belanja yang dianggarkan tidak terkait langsung dengan pelaksanaan program dan kegiatan. Seperti belanja pegawai berupa gaji dan 
tunjangan yang telah ditetapkan oleh undang-undang, belanja bunga, belanja hibah, belanja bantuan sosial, belanja bagi hasil kepada provinsi/kabupaten/kota dan pemerintah.

a. Belanja pegawai adalah belanja kompensasi, baik dalam bentuk uang maupun barang yang ditetapkan berdasarkan ketentuan perundang-undangan yang diberikan kepada DPRD dan pegawai pemerintah daerah baik yang bertugas di dalam maupun di luar daerah sebagai imbalan atas pekerjaan yang telah dilaksanakan.

b. Belanja bunga adalah pembayaran bunga utang, pembayaran yang dilakukan atas kewajiban penggunaan pokok utang yang dihitung berdasarkan posisi pinjaman jangka pendek atau jangka panjang.

c. Belanja subsidi adalah alokasi anggaran yang diberikan kepada perusahaan/lembaga tertentu yang bertujuan untuk membantu biaya produksi agar harga jual produksi/jasa yang dihasilkan dapat terjangkau oleh masyarakat banyak.

d. Belanja hibah adalah belanja yang diperlukan untuk menganggarkan pemberian uang barang atau jasa kepada pemerintah atau pemerintah daerah lainnya.

e. Belanja bantuan sosial adalah pemberian bantuan yang sifatnya tidak secara terus menerus dan selektif dalam bentuk uang/barang kepada masyarakat yang bertujuan untuk peningkatan kesejahteraan masyarakat.

f. Belanja bagi hasil kepada provinsi/kabupaten/kota dan pemerintah desa adalah belanja yang telah dianggarkan sebagai dana bagi hasil yang bersumber dari pendapatan kabupaten/kota kepada provinsi, kabupaten/kota, desa atau pendapatan pemerintah daerah tertentu kepada pemerintah daerah lainnya sesuai dengan ketentuan perundang-undangan.

\section{Investasi}

Menurut Mankiw (2007) investasi merupakan unsur GDP yang paling sering berubah ketika pengeluaran atas barang dan jasa turun selama resesi, sebagian besar dari penurunan itu berkaitan dengan anjloknya pengeluaran investasi. Ada tiga bentuk pengeluaran investasi, investasi tetap bisnis (business fixed investmen) mencakup peralatan struktur yang perusahaan beli untuk proses produksi, investasi residensil (residential investment) mencakup perumahan baru yang orang beli untuk di tinggal dan yang di beli tuan tanah untuk disewakan, investasi persediaan (inventory investment) mencakup barangbarang yang perusahaan tempatkan di gudang termasuk bahan-bahan dan perlengkapan barang setengah jadi dan barang jadi. 
Berdasarkan jenisnya investasi dibagi menjadi dua jenis, yaitu: pertama investasi pemerintah, adalah investasi yang dilakukan oleh pemerintah pusat maupun pemerintah daerah. Pada umumnya investasi yang dilakukan oleh pemerintah tidak dimaksudkan untuk memperoleh keuntungan; kedua investasi swasta, adalah investasi yang dilakukan oleh sektor swasta nasional yaitu Penanaman Modal Dalam Negeri (PMDN) ataupun investasi yang dilakukan oleh swasta asing yang disebut Penanaman Modal Asing (PMA). Investasi dapat diartikan sebagai pengeluaran penanam-penanam modal atau perusahaan untuk membeli barang-barang modal dan perlengkapan-perlengkapan produksi untuk menambah kemampuan memproduksi barang-barang dan jasa-jasa dalam perekonomian. Dengan perkataan lain, dalam teori ekonomi investasi berarti kegiatan perbelanjaan untuk meningkatkan kapasitas memproduksi sesuatu dalam perekonomian. Pertambahan jumlah barang modal ini memungkinkan perekonomian tersebut menghasilkan lebih banyak barang dan jasa dimasa yang akan datang. Adakalanya penanaman modal ini dilakukan untuk menggantikan barang-barang modal yang lama yang telah haus dan perlu didepresiasikan.

Ada beberapa faktor-faktor yang mempengaruhi tingkat investasi antara lain: (1) tingkat pengembalian ynag diharapkan (Expected Rate of Return). Kemampuan perusahaan menetukan tingkat investasi yang diharapkan, sangat dipengaruhi oleh kondisi internal dan eksternal perusahaan.Kondisi internal adalah faktor-faktor yang berada di bawah control perusahaan. Kondisi eksternal yang perlu di pertimbangkan dalam pengambilan keputusan akan investasi terutama adalah perkiraan tentang tingkat produksi dan pertumbuhan ekonomi domestic dan internasional. (2) biaya investasi, yang paling menentukan tingkat biaya investasi adalah tingkat bunga pinjaman; makin tinggi tingkat bunganya, maka biaya investasi makin mahal. Akibatnya minat berinvestasi makin menurun. (3) Marginal Efficiency of Capital (MEC), tingkat bunga, dan Marginal Efficiency of Investment (MEI). Sebagai sebuah keputusan yang rasional, investasi sangat ditentukan oleh dua faktor utama, yaitu tingkat pengembalian yang diharapkan dan biaya investasi.

\section{METODE PENELITIAN / METHODS}

Metode penelitian yang yang digunakan dalam penelitian ini adalah metode kuanitatif. Dalam metode ini statistika alat analisis yang dipakai dalam penelitian ini adalah 
analisis regresi. Analisis regresi merupakan studi atas ketergantungan suatu variabel yaitu variabel yang tergantung pada variabel yang lain yang disebut dengan variabel bebas dengan tujuan untuk mengestimasi dengan meramalkan nilai populasi berdasarkan nilai tertentu dari variabel yang diketahui. Model analisis yang digunakan dalam penelitian ini adalah model analisis inferensial, yaitu analisis regresi berganda untuk mengetahui pengaruh konsumsi rumah tangga, belanja pemerintah, dan investasi terhadap pertumbuhan ekonomi di Kabupaten Polewali Mandar. Sumber data dalam penelitian ini adalah berbagai macam sumber yang diperoleh melalui data sekunder yang berasal dari Iaporan Badan Pusat Statistik Kabupaten Polewali Mandar pada kurun waktu 10 tahun terakhir (2008-2017). Adapun persamaan regresi tersebut dapat ditransformasikan kedalam fungsi berikut:

$\operatorname{Ln} Y=\beta_{0}+\beta_{1} \operatorname{Ln} X_{1}+\beta_{2} \operatorname{Ln} X_{2}+\beta_{3} \operatorname{Ln} X_{3} \mu$

Dimana:

$\begin{array}{ll}\mathrm{Y} & =\text { Pertumbuhan Ekonomi (\%) } \\ \mathrm{X} 1 & =\text { Konsumsi Rumah Tangga (Rp) } \\ \mathrm{X} 2 & =\text { Belanja Pemerintah (Rp) } \\ \mathrm{X} 3 & =\text { Investasi (Rp) } \\ \beta_{0} & =\text { Konstanta } \\ \beta_{1}-\beta_{3} & =\text { Parameter } \\ \mu & =\text { Error Term }\end{array}$

\section{HASIL DAN PEMBAHASAN / DISCUSSION}

\section{A. Hasil Analisis Data}

1. Uji Asumsi Klasik

Evaluasi ini dimaksudkan untuk menguji apakah penggunaan model regresi linear berganda (multiple regression linear) dalam menganalisis telah memenuhi asumsi klasik. Model linear berganda akan lebih tepat digunakan dan menghasilkan perhitungan yang lebih akurat apabila asumsi-asumsi berikut dapat terpenuhi yaitu:

\section{a. Uji Normalitas}

Uji normalitas bertujuan untuk menguji apakah dalam model regresi, variabel terikat maupun variabel bebas keduanya mempunyai distribusi normal atau tidak. Model regresi yang baik adalah memiliki distribusi normal atau mendekati normal. Salah satu 
metode untuk mengetahui suatu normalitas adalah dengan menggunakan metode analisis grafik, yaitu baik dengan melihat grafik secara histogram ataupun dengan melihat secara Normaln Probability Plot. Normalitas suatu data dapat dilihat dari penyebaran data (titik) pada sumbu diagonal pada grafik normal P-Plot atau dengan melihat histogram dari residualnya.

\section{Gambar 1: Grafik Histogram}

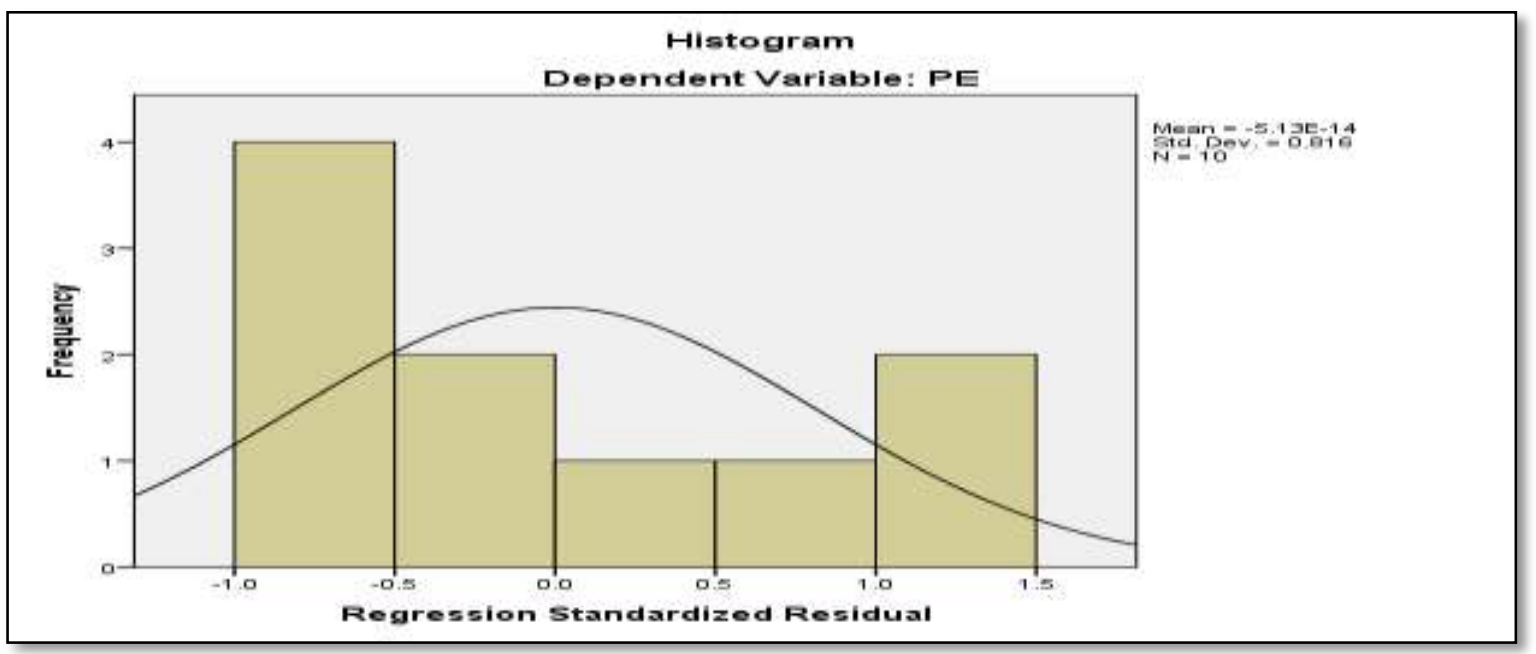

Sumber: Output SPSS 21 (data sekunder diolah 2018)

Gambar 2: Grafik Uji Normalitas

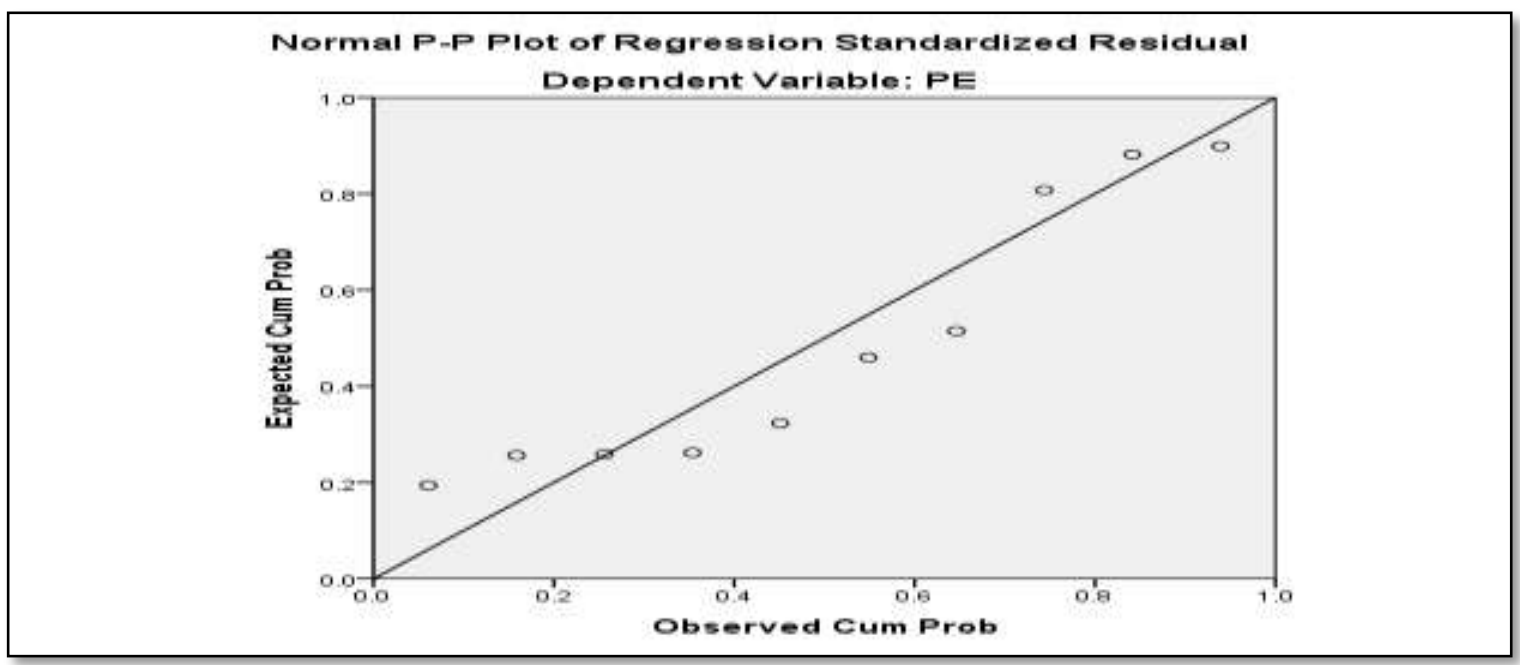

Sumber: Output SPSS 21 (data sekunder diolah 2018) 
Nurfadillah, Aisyah Mengurai Relasi Konsumsi Rumah Tangga ...

Pola distribusi mendekati normal, karena data mengikuti arah garis grafik histogramnya. Sebagaimana terlihat dalam grafik Normal P-Plot of regression Standardized Residual, terlihat bahwa titik-titik menyebar disekitar garis diagonal (membentuk garis lurus), maka dapat dikatakan bahwa data berdistribusi normal dan model regresi layak dipakai untuk memprediksi pertumbuhan ekonomi berdasarkan variabel bebasnya.

\section{b. Uji Autokolerasi}

Tabel 1: Hasil Uji Autokolerasi

\begin{tabular}{|c|c|c|c|c|c|}
\hline Model & $\mathrm{R}$ & R Square & Adjusted $\mathrm{R}$ & Std. Error of the & Durbin-Watson \\
\hline & & & Square & Estimate & \\
\hline 1 & $.986^{\mathrm{a}}$ & .972 & & .14659 & 2.087 \\
\hline
\end{tabular}

Sumber : Output SPSS 21(data sekunder diolah, 2018)

Salah satu metode analisis untuk mendeteksi ada tidaknya suatu autokolerasi dengan melakukan pengujian nilai durbin watson (DW test). Jika nila DW lebih besar dari batas atas (du) dan kurang dari jumlah variabel independen, maka dapat disimpulkan bahwa tidak ada autokolerasi.

Tabel tersebut menunjukkan nilai sebesar 2,087. Nilai ini akan dibandingkan dengan nilai tabel dengan menggunakan nilai signifikan 0,05 dengan jumlah sampel sebanyak 10 (n) dan variabel independen $3(\mathrm{k}=3)$, oleh karena itu nilai DW test sebesar 2,087 lebih besar dari batas atas (dw) 2,0163 dan kurang dari 4-2,0163 maka dapat disimpulkan bahwa tidak ada autokorelasi positif/negatif dengan kata lain tidak terdapat autokorelasi.

\section{c. Uji Multikolinieritas}

Tujuan dari pengujian ini untuk menguji apakah pada model regresi ditemukan adanya korelasi antar variabel bebas. Variable bebas tersebut, dapat dilihat melalui VIF (variance inflation factor) dari masing-masing variabel bebas terhadap variabel terikat. Apabila nilai VIF tidak lebih dari 5 berarti mengindikasikan bahwa dalam model tidak terdapat multikolinieritas, besaran VIF (variance inflation factor) dan tolerance.

Nilai VIF untuk variabel Konsumsi rumah tangga sebesar 94,020 > 10 dan nilai toleransi sebesar 0,011 0,10 sehingga variabel Konsumsi rumah tangga dinyatakan terjadi gejala Multikolinearitas. Nilai VIF untuk variabel Belanja pemerintah sebesar 75,988 > 10 dan nilai toleransi sebesar $0,13>0,10$ sehingga variabel belanja pemerintah dinyatakan terjadi 
Multikolinearitas. Nilai VIF variabel tingkat Investasi sebesar 289,179 > 10 dan nilai toleransi sebesar $0,003<0,10$, sehingga variabel tingkat Investasi terjadi gejala Multikolinearitas.

Tabel 2: Uji Multikolinieritas

\begin{tabular}{llr}
\hline Model & \multicolumn{2}{c}{ Collinearity Statistics } \\
\hline \multicolumn{2}{l}{ Tolerance } & VIF \\
\hline (Constant) & & 94.020 \\
KRT & .011 & 75.988 \\
BP & .013 & 286.179 \\
INV & .003 &
\end{tabular}

Sumber : Output SPSS 21 (data sekunder diolah, 2018)

\section{d. Uji Heteroskedastisitas}

Model regresi yang baik adalah tidak terjadi Heteroskedastisitas. Hasil dari pengujian ini menunjukkan, titik menyebar secara acak dan tidak membentuk suatu pola tertentu yang jelas, serta tersebar baik di atas dan dibawah angka 0 pada sumbu Y. Hal ini berarti tidak terjadi masalah heteroskedastisitas.

Gambar 3: Grafik Uji Heterokedastisitas

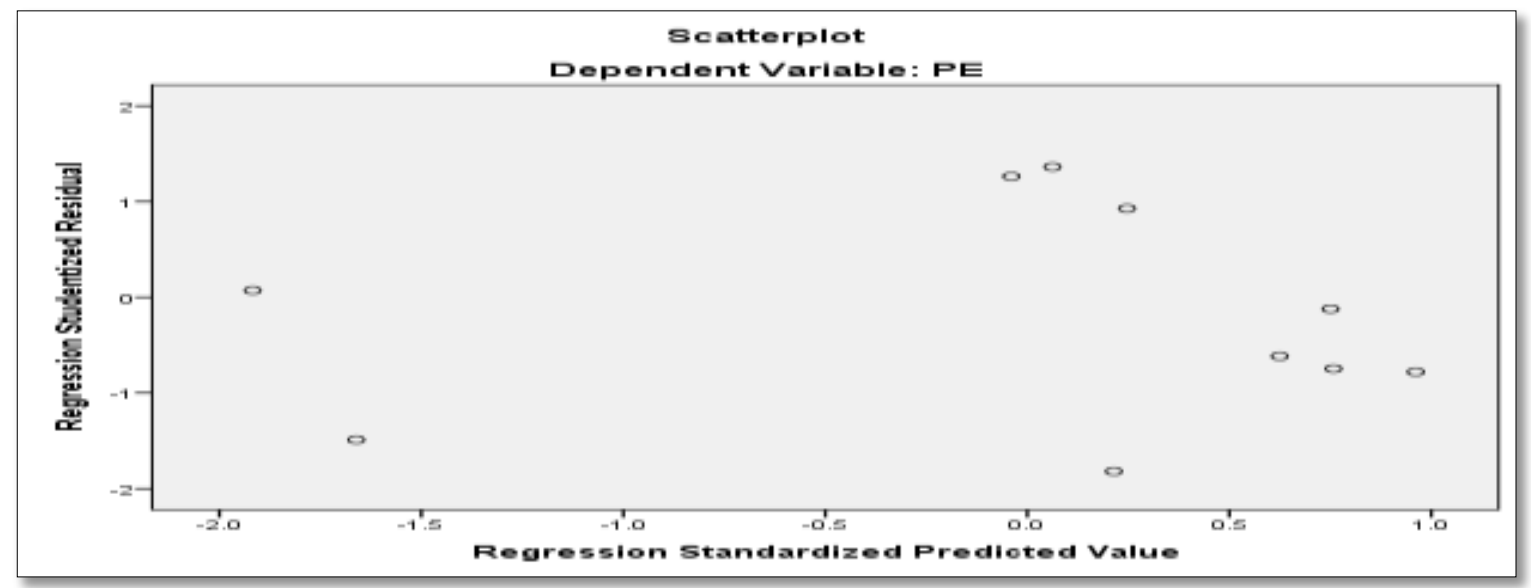

Sumber : Output SPSS 21(data sekunder diolah, 2018)

\section{Pengujian Regresi Linear Berganda}

Analisis regresi dilakukan untuk mengetahui tingkat pengaruh variabel bebas terhadap suatu variabel terikat, baik secara simultan maupun secara parsial, serta menguji 
hipotesis penelitian yang telah ditetapkan sebelumnya, berikut hasil rekapitulasi regresi berganda:

Tabel 3: Rekapitulasi hasil Analisis Regresi Berganda

\begin{tabular}{|c|c|c|c|c|c|}
\hline \multirow[t]{2}{*}{ Model } & \multicolumn{2}{|c|}{$\begin{array}{l}\text { Unstandardized } \\
\text { Coefficients }\end{array}$} & \multirow{2}{*}{$\begin{array}{c}\text { Standardized } \\
\text { Coefficients }\end{array}$} & \multirow[t]{2}{*}{$\mathrm{T}$} & \multirow[t]{2}{*}{ Sign } \\
\hline & B & Std. Error & & & \\
\hline (Constant) & -27.066 & 5.178 & & -5.227 & .002 \\
\hline KRT & 7.837 & 1.832 & 2.848 & 4.279 & .005 \\
\hline BP & 1.799 & 1.399 & .769 & 1.286 & 0.246 \\
\hline INV & -5.579 & 2.444 & -2.651 & -2.283 & 0.63 \\
\hline
\end{tabular}

Sumber :Output SPSS 21(data sekunder diolah, 2018)

Berdasarkan pada tabel berikut terlihat bahwa nilai konstanta a sebesar -27,066 dan koefisien regresi (b1) sebesar 7,837, dan (b2) sebesar .1,799, dan (b3) sebesar $-5,579$. Nilai konstanta dan koefisien regresi $(a, b 1, b 2$.b3) ini dimaksudkan dalam persamaan regresi linear berganda sebagai berikut:

$$
Y=-27,066+7,837+1,799-5,579
$$

Dari persamaan regresi berganda diatas dapat dilihat bahwa nilai konstanta sebesar -27,066 berarti jika Konsumsi rumah tangga (X1), Belanja pemerintah (X2), dan Investasi (X3) nilainya 0 atau konstan maka pertumbuhan ekonomi ( $Y$ ) nilainya sebesar $-27,066$ apabila koefisien regresi konsumsi rumah tangga (X1) meningkat $1 \%$ dengan asumsi variabel independen lainnya tetap maka pertumbuhan ekonomi (Y) meningkat sebesar 7,837 begitu juga seterusnya dengan variabel independent lainnya.

\section{Pengujian Hipotesis}

Selanjutnya dari persamaan regresi berganda dilakukan uji statistik dengan prosedur pengujiannya sebagai berikut:

\section{a. Uji Koefisien Determinan $\left(\mathbf{R}^{2}\right)$}

Uji koefisien determinan ( $R$ squre) pada intinya yaitu mengukur seberapa besar kemampuan model dalam menerangkan variasi variabel dependennya. Nilai koefisien determinan yang mendekati satu variabel independennya menjelaskan hampir semua informasi yang dibutuhkan untuk memproduksi pada variabel dependen. Hasil perhitungan koefisien determinasi penelitian ini dapat dilihat pada tabel berikut: 
Tabel 4: Hasil Perhitungan Koefisien Determinasi (R square)

\begin{tabular}{|c|c|c|c|c|}
\hline \multirow[t]{3}{*}{ Model } & \multirow[t]{3}{*}{$\mathrm{R}$} & Adjusted R & \multirow{3}{*}{$\begin{array}{l}\text { Std. Error of } \\
\text { the Estimate }\end{array}$} & Change Statistics \\
\hline & & \multirow[t]{2}{*}{ Square Square } & & R Square \\
\hline & & & & Change \\
\hline 1 & $.986^{\mathrm{a}}$ & .972 & .14659 & 68.742 \\
\hline
\end{tabular}

Sumber : Output SPSS 21 (data sekunder diolah, 2018)

Berdasarkan tabel diatas tampak bahwa hasil dari perhitungan diperoleh nilai koefisien determinasi ( $R$ square) sebesar 0,972 dengan kata lain hal ini menunjukkan bahwa besar persentase variasi tingkat Pertumbuhan Ekonomi yang bisa dijelaskan oleh variasi dari ketiga variabel bebas yaitu Konsumsi Rumah Tangga, Belanja Pemerintah dan Investasi sebesar $97,2 \%$ sedangkan sisanya sebesar 2,8\% dijelaskan oleh variabel-variabel lainnya yang diluar penelitian.

\section{b. Uji F (Secara Simultan)}

Uji F statistik pada dasarnya menunjukkan apakah semua variabel independen yang dimasukkan dalam model mempunyai pengaruh secara bersama sama terhadap variabel dependennya. Hasil perhitungan Uji F ini dapat dilihat pada tabel berikut:

Tabel 5: Hasil Perhitungan Uji F (Secara Simultan) Anova

\begin{tabular}{|c|c|c|c|c|c|c|}
\hline \multicolumn{2}{|l|}{ Model } & $\begin{array}{l}\text { Sum of } \\
\text { Squares }\end{array}$ & Df & Mean Square & $F$ & Sig. \\
\hline \multirow{3}{*}{1} & Regression & 4.432 & 3 & 1.477 & 68.742 & $.000^{\mathrm{b}}$ \\
\hline & Residual & .129 & 6 & .021 & & \\
\hline & Total & 4.560 & 9 & & & \\
\hline
\end{tabular}

Sumber : Output SPSS 21(data sekunder diolah, 2018)

Hasil regresi yang ditunjukkan pada tabel diatas, pengaruh variabel Konsumsi Rumah Tangga $\left(X_{1}\right)$, Belanja Pemerintah $(X 2)$, dan Investasi $\left(X_{3}\right)$ terhadap Pertumbuhan Ekonomi (Y), maka diperoleh nilai signifikan $0,000<0,05$. Hal ini menunjukkan bahwa ketiga variabel bebas secara simultan berpengaruh signifikan terhadap variabel terikat.

\section{c. Uji t (Secara Parsial)}

Untuk mengetahui pengaruh masing-masing atau secara parsial variabel independen (Konsumsi Rumah Tangga, Belanja Pemerintah, Investasi) terhadap variabel 
Nurfadillah, Aisyah Mengurai Relasi Konsumsi Rumah Tangga ...

dependen ( Pertumbuhan Ekonomi), sementara itu secara parsial pengaruh dari ketiga variabel independen tersebut terhadap Pertumbuhan Ekonomi ditunjukkan pada tabel berikut:

Tabel 6: Hasil Perhitungan Uji t (Secara Parsial) Coefficients ${ }^{a}$

\begin{tabular}{rlrrrrr}
\hline Model & & \multicolumn{2}{c}{$\begin{array}{c}\text { Unstandardized } \\
\text { Coefficients }\end{array}$} & $\begin{array}{c}\text { Standardized } \\
\text { Coefficients }\end{array}$ & t & Sig. \\
\cline { 3 - 5 } & & \multicolumn{1}{c}{ B } & \multicolumn{1}{c}{ Std. Error } & Beta & & \\
\hline \multirow{2}{*}{1} & (Constant) & -27.066 & 5.178 & & -5.227 & .002 \\
& KRT & 7.837 & 1.832 & 2.848 & 4.279 & .005 \\
& BP & 1.799 & 1.399 & .769 & 1.286 & .246 \\
& INV & -5.579 & 2.444 & -2.651 & -2.283 & .063 \\
\hline
\end{tabular}

Sumber : Output SPSS 21(data sekunder diolah, 2018).

Pengaruh masing-masing variabel Konsumsi Rumah Tangga, Belanja Pemerintah dan Investasi terhadap Pertumbuhan Ekonomi dapat dilihat dari arah tanda dan tingkat signifikan. Variabel Konsumsi Rumah Tangga memiliki tingkat signifikan 0,005 0.05 yang artinya variabel Konsumsi Rumah Tangga berpengaruh secara singnifikan dan berhubungan positif terhadap Pertumbuhan Ekonomi, variabel Belanja Pemerintah memiliki tingkat signifikan sebesar 0,246>0,05 yang artinya variabel Belanja Pemerintah tidak berpengaruh signifikan tetapi berhubungan positif terhadap pertumbuhan ekonomi, begitu juga dengan variabel tingkat Investasi memiliki tingkat signifikan 0,063 $>0,05$, yang artinya variabel Investasi tidak berpengaruh secara signifikan tetapi berhubungan positif terhadap pertumbuhan ekonomi.

\section{B. Pembahasan}

Hasil pengujian hipotesis masing-masing variabel dependen secara parsial terhadap variabel dependennya dapat dianalisis sebagai berikut:

1) Pengaruh Konsumsi Rumah Tangga Terhadap Pertumbuhan Ekonomi.

Dari tabel menunjukkan bahwa nilai signifikan Tingkat Konsumsi Rumah Tangga sebesar 0,005 bila dibandingkan dengan taraf signifikan a $(0,05)$, menunjukkan nilai signifikan lebih kecil dibandingkan dengan nilai taraf signifikan $(0,005<0,05)$, dengan demikian Tingkat Konsumsi Rumah Tangga berpengaruh secara signifikan dan berpengaruh positif terhadap Pertumbuhan Ekonomi di Kabupaten Polewali Mandar. 
Berdasarkan hasil regresi pada penelitian ini, konsumsi rumah tangga berpengaruh secara signifikan dan berhubungan positif terhadap pertumbuhan ekonomi. Hal ini disebabkan karena pendapatan yang diperoleh oleh rumah tangga digunakan untuk memenuhi kebutuhannya, karena adanya keinginan memiliki dan menggunakan barang atau jasa tersebut tersebut, jadi semakin besar perputaran ekonomi yang terjadi di masyarakat, maka akan berdampak positif terhadap pertumbuhan ekonomi. Pengeluaran Konsumsi Rumah Tangga merupakan nilai belanja yang dilakukan oleh suatu rumah tangga untuk membeli berbagai jenis kebutuhannya dalam satu tahun tertentu. Suatu pendapatan yang diterima oleh rumah tangga akan digunakan untuk membeli pakaian, makanan, biaya jasa pengangkutan, sewa rumah, membeli kendaraan, dan membayar pendidikan anak. barangbarang tersebut dibeli oleh suatu rumah tangga untuk memenuhi kebutuhannya.

Semakin besar pendapatan rumah tangga yang dimiliki seseorang maka semakin besar pula tingkat pengeluaran konsumsi, dan jika tingkat pengeluaran konsumsi naik maka akan berpengaruh positif pula terhadap pertumbuhan ekonomi. Alasan mengapa dikatakan bahwa suatu Konsumsi Rumah Tangga positif dengan pertumbuhan ekonomi adalah adanya korelasi positif antara tingkat pendapatan seseorang akan cenderung meningkat pola konsumsi mereka yang nantinya akan meningkatkan permintaan di sektor konsumsi yang merupakan bagian dari suatu permintaan agregat yang mampu mendorong suatu Pertumbuhan Ekonomi.

Keputusan konsumsi rumah tangga dipengaruhi keseluruhan perilaku baik jangka pendek maupun jangka panjang. keputusan konsumsi rumah tangga untuk jangka panjang adalah penting karena peranannya dalam pertumbuhan ekonomi. sedangkan untuk analisis jangka pendek adalah peranannya penting dalam menentukan permintaan agregat. pengeluaran konsumsi yang dilakukan oleh suatu rumah tangga dalam perekonomian tergantung pada pendapatan yang diterima oleh mereka. semakin besar pendapatan maka semakin besar pula konsumsinya, (Dumairy,1996).

Hasil Penelitian ini sejalan dengan hasil penelitian yang dilakukan oleh Deprianto (2011), yang berjudul pengaruh konsumsi dan investasi terhadap pertumbuhan ekonomi di Kota Padang yang menyatakan bahwa pengeluaran konsumsi rumah tangga berpengaruh secara positif dan signifikan terhadap pertumbuhan ekonomi di Kota Padang. Pertama, selera sebuah rumah tangga atas barang konsumsi adalah interdependen. Artinya, bahwa 
pengeluaran konsumsi rumah tangga dipengaruhi oleh pengeluaran yang dilakukan oleh orang yang ada disekitarnya (tetangganya), sedangkan yang kedua, pengeluaran konsumsi adalah irrevesible. Artinya pola pengeluaran seseorang pada saat penghasilan mengalami penurunan.

2) Pengaruh Belanja Pemerintah Terhadap Pertumbuhan Ekonomi.

Table menunjukkan bahwa nilai signifikan variabel belanja pemerintah sebesar 0,246 bila dibandingkan dengan taraf signifikan a $(0,05)$, menunjukkan nilai signifikan lebih besar dibandingkan dengan nilai taraf signifikan $(0,246>0,05)$, maka dapat disimpulkan bahwa variabel belanja pemerintah tidak berpengaruh secara signifikan tetapi berhubungan positif terhadap pertumbuhan ekonomi di Kabupaten Polewali Mandar.

Berdasarkan hasil regresi pada penelitian ini, belanja pemerintah tidak berpengaruh secara signifikan tetapi berhubungan positif terhadap pertumbuhan ekonomi. Hal ini disebabkan karena peranan atau campur tangan pemerintah masih sangat diperlukan yaitu apabila perekonomian sepenuhnya diatur oleh kegiatan dipasar bebas, maka perlu pengawasan dari pemerintah agar pelaku usaha tidak semenah-menah dalam menentukan tingkat harga. Hasil penelitian ini sejalan dengan hasil penelitian yang dilakukan oleh Agus Indrianto Kurniawan DKK (2017), yang menyatakan bahwa variabel Belanja Pemerintah tidak berpengaruh signifikan tetapi berhubungan positif terhadap Pertumbuhan Ekonomi di Kabupaten Kutai Barat.

3) Pengaruh Investasi Terhadap Pertumbuhan Ekonomi.

Tabel menunjukkan bahwa nilai signifikan variabel Investasi sebesar 0,063 bila dibandingkan dengan taraf signifikan a $(0,05)$, menunjukkan nilai signifikan lebih besar dibandingkan dengan nilai taraf signifikan $(0,063>0,05)$, sehingga $\mathrm{H}_{0}$ ditolak dan $\mathrm{H}_{1}$ diterima, dengan demikian Tingkat Investasi tidak berpengaruh secara signifikan tetapi berhubungan positif terhadap Pertumbuhan Ekonomi di Kabupaten Polewali Mandar. Berdasarkan hasil regresi pada penelitian ini, investasi tidak berpengaruh secara signifikan tetapi berhubungan positif terhadap pertumbuhan ekonomi. Hal ini disebabkan karena salah satu faktor yang menentukan tingkat investasi adalah tingkat bunga pinjaman, makin tinggi tingkat bunga pinjaman, maka biaya investasi makin mahal. Akibatnya minat berinvestasi makin menurun.

Dalam konteks pembangunan terutama di negara-negara yang sedang berkembang, investasi merupakan sasaran utama yang kontribusinya sangat diandalkan dalam mengejar target pertumbuhan ekonomi yang lebih cepat terutama dalam mengembangkan tingkat pertumbuhan pendapatan asli daerah. Disamping itu juga kenaikan 
dalam investasi suatu negara tidak lepas dari investasi asing. Hasil penelitian ini sejalan dengan hasil penelitian yang dilakukan oleh Agus Indrianto Kurniawan, DKK (2017), yang menyatakan bahwa variabel Investasi tidak berpengaruh signifikan tetapi berhubungan positif terhadap Pertumbuhan Ekonomi di Kabupaten Kutai Barat.

\section{KESIMPULAN / CONCLUSION}

Berdasarkan hasil penelitian ini ditemukan beberapa hal penting, untuk mengurai relasi pengaruh konsumsi rumah tangga, belanja pemerintah dan investasi terhadap pertumbuhan ekonomi. Pertama, nampaknya konsumsi rumah tangga berpengaruh secara positif dan signifikan terhadap Pertumbuhan Ekonomi di Kabupaten Polewali Mandar. Kedua, belanja pemerintah tidak berpengaruh signifikan terhadap Pertumbuhan Ekonomi di Kabupaten Polewali Mandar. Ketiga, investasi tidak berpengaruh signifikan terhadap Pertumbuhan Ekonomi di Kabupaten Polewali Mandar. Keempat, konsumsi rumah tangga, belanja pemerintah dan investasi secara bersama-sama berpengaruh terhadap pertumbuhan ekonomi. Pemerintah Kabupaten Polewali Mandar diharapkan untuk lebih memberikan perhatian khusus kepada masyarakat dalam mengonsumsi makanan yang seharusnya di konsumsi sesuai dengan kebutuhan tubuh menurut usia (melakukan konsumsi makanan berdasarkan pola makan yang benar). Pemerintah Kabupaten Polewali Mandar diharapkan mengalokasikan belanja pemerintah secara proporsional antara belanja rutin yang konsumtif dengan belanja pembangunan yang lebih memihak pada suatu kepentingan publik sehingga dapat memberikan efek yang positif. Pemerintah Kabupaten Polewali Mandar diharapkan untuk dapat menarik para investor dengan cara menciptakan iklim positif yang kondusif, meningkatkan kualitas sumber daya manusia, serta pembuatan peta potensi daerah dan pembentukan unit pelayanan terpadu di daerah untuk mempermudah pelayanan pembuatan ijin usaha dan investasi.

\section{DAFTAR PUSTAKA / REFERENCES}

Agus Indrianto Kurniawan, dkk. 2017. Pengaruh Investasi Swasta dan Pengeluaran Pemerintah Serta Tenaga Kerja Terhadap Pendapatan Asli Daerah dan 
Pertumbuhan Ekonomi. (Jurnal Ekonomi, 2017).Amartya, Sen, 1999. Development as Freedom, Alfred Knopf, New York.

Deprianto, Asrizal, Jolianis, Pengaruh konsumsi dan investasi terhadap pertumbuhan ekonomi di Kota Padang.(jurnal Ekonomi, 2012).

Dumairy, Perekonomian Indonesia, (Cetakan kelima, Jakarta, Erlangga, 1996), h.114.

Mangkoesoebroto, Guritno. 2008. Ekonomi Publik, Edisi ketiga. BPFE, Yogyakarta. Mankiw, G. (2007). Makroekonomi. Edisi keenam. Jakarta: Erlangga

Smith, Adam. 1759. "The Theory of Moral Sentiments." Edited by: Knud Haakonssen. Cambridge: Cambridge University Press.

Salvatore, D\& Dowling, E.T, 2006, Theory And Problems at Economic Development, McGraw Hill, New York. 